\title{
Protein Tyrosine Phosphatase Gene
}

National Cancer Institute

\section{Source}

National Cancer Institute. Protein Tyrosine Phosphatase Gene. NCI Thesaurus. Code C26059.

Protein Tyrosine Phosphatase Genes encode Protein Tyrosine Phosphatases, enzymes that specifically remove tyrosine-bound phosphate groups from many phosphoproteins, including many enzymes phosphorylated by a tyrosine kinase. Together with protein tyrosine kinases, Tyrosine Phosphatases regulate tyrosine phosphorylation and dephosphorylation in cellular signal transduction and may play a role in cell growth control and carcinogenesis. $(\mathrm{NCl})$ 